\title{
Determinant of Loan Supply Behavior: The case of Regional Development Banks in East Indonesia
}

\author{
Jusni ${ }^{1}$ Andi Aswan ${ }^{2}$
}

This study is intended to assist the Regional Development Banks in Eastern Indonesia to increase their loan volume. The collected time series data in the period of $2011-2016$ was analyzed using a multiple regression analysis with the use of SPSS version 23 of the software package. The statistical results of the t-individual test indicate that personnel cost, GRDP, promotional cost and deposit funds affect positively and significantly loan volume. The overall F-test of the four studied variables also indicates a positive and significant result.

Key Words: Loan Volume, RDB, Personnel Cost, Promotion Cost, Deposit Funds, GRDP.

This is a research in Management

${ }^{1}$ Department of Management, Faculty of Economics and Business, Hasanuddin University. Jln. Perintis Kemerdekaan KM. 10, Tamalanrea. jusni mju@yahoo.co.id

${ }^{2}$ Department of Management, Faculty of Economics and Business, Hasanuddin University. Jln. Perintis Kemerdekaan KM. 10, Tamalanrea. andiaswanp@yahoo.com 
The study is intended to assist to increase the intermediary function of the regional development banks operated in the east Indonesia by expanding more credit portfolio. As it has been known in many kinds of literature (e.g. Macerinskine \& Laura, 2008 and Hanweck \& Ryu, 2005) that loan is the highest promising earnings for banks compared with other investment portfolios. With such high prospect of return, bank including regional development banks should prefer to invest the collected funds to its loan portfolios.

Apart from a possible high return earned from loan portfolios, banks are also required to disburse loans in performing their intermediary functions. Funds collected from third parties are required to be re-channeled in various forms of loan portfolios. As a measure of the performance of the intermediary function, Central Bank of Indonesia implements a Loan To Deposit Ratio (LDR) which is subsequently replaced by Loan to Funding Ratio (LFR) for commercial banks (Wahyuningsih \& Swandari, 2016 and Quadrant \& Suriani, 2017 and Wahyuningsih, Oemar, Supriyanto, 2017) and Financing Deposit Ratio for Sharia Banks and Sharia Unit (Agustina, Djaelani \& Priyono, 2017). Currently, the minimum limit required for commercial banks for the achievement of LFR ratio is $78 \%$ and the maximum limit is $92 \%$ (e.g. Berhardin, 2016).

In relation to the existing literature, there is an extensive of literature studying loan supply behavior of commercial banks from various countries, such as in Jordanian (Elletter \& Yaseen, 2017), in China (Chi \& Li, 2017) in Kenya (Njeru, Mohhamed \& Wachira, 2017), in India (Ramcharran, 2017) and in Croatia (Škalamera-Alilović \& Štambuk, 2017). In Indonesia, researchers related to individual bank and bank level are also frequently conducted primarily instated and private commercial banks. It is also valid for Regional Development Banks (e.g. Liem, Masjud, Candra, 2017 and Riyadi, 2017). A few scholars also studied whole commercial banks (Anwar, 2017 and Rokhim \& Marmidy, 2017). Nevertheless, most loan supply studies focus on financial ratios such as profitability ratios, profitability ratios, and other ratios (Liem, Masjud, Candra, 2017 Wibowo \& Syaichu, 2013; and Raharjoet al, 2014).

Different from other scholars, this study does not focus on the aspect of financial ratios. In relation to credit, this study attempts to relate the amount of personnel cost, advertising and promotional cost, and the collected deposit funds and GRDP variables to loan volume. The first two mentioned variables, to the best of our knowledge, do not ever take into account by scholars. In fact, these two variables can possibly influence credit performance. This is quite rational because promotional costs will improve the image of the bank that can make customers to apply for credits (Škalamera-Alilović \& Štambuk, 2017; Black \& Strahan, 2002; and Carter et al., 2007). This is also true for the variable of personnel cost that can be associated with motivation factors. Employee costs, one of which is salary, will most likely have implications for the employee's willingness to take more loan supply decision which then possibly could increase loan volume (e.g Almossawi, 2001; Almazan \& Suarez, 2003; and Lepitit et al, 2008).

If it is related to measurement, it is generally credits measured by LDR or FDR ratio (Rosengard \& Prasetyantoko, 2011; Pelealu, Karamoy, Poputra, 2017, Wahyuningsih \& Swandari, 2016 and Quadrant \& Suriani, 2017 and Wahyuningsih, Oemar, Supriyanto, 2017). Only a small number of researchers does use the credit volume to measure credit performance (e.g Satria \& Subegti, 2010; Sukarno \& Syaichu, 2006; and Triasdini \& Arfianto, 2010; Anindita \& Arfianto, 2011). 
Another feature of this research is in geographical coverage. Generally, research on regional banks is only at the individual bank level, such as Sulselbar Bank, Jambi Bank and so on. Many researchers study the local banks by taking almost all of the samples of local banks operated within Indonesia. In contrast to other studies, this area of research is only in the geographic area of eastern Indonesia. Thus, the possible biases resulting from fundamental differences such as the concentration of economic activity and the velocity of funds will be avoided. In addition, the assumption of differences in economic characteristics between provinces in Eastern Indonesia is not too obvious. In other words, it can be assumed that the bank tends to have the same pattern and behavior in making loan supply decision.

Based on the above explanation, this study examines how advertising and promotional costs, labor costs, deposit funds, GRDP affect loan volume.

\section{Loan Disbursement}

As a financial institution, banks are required to perform the intermediation function. Banks are given the authority to collect funds from societies in the form of various loan products (demand deposits, savings deposits, time deposits) (Taswan, 2010; Riyadi, 2006; and Rivai \& Veithzal, 2007). The collected funds have then to be redistributed in the form of the loan portfolio (Taswan, 2010 and Rivai \& Veithzal, 2007). Banks are bounded by that role and supervised and controlled by Bank Central Indonesia and the Financial Services Authority for the achievement.

Related to the funds channeling, banks have decisional options in their investment portfolio (Riyadi, 2006), including to place funds collected into primary reserves, secondary reserves, fixed assets, or loan portfolios. Certainly, every decision made affects other investment opportunities. When it comes to placing funds into other banks, it can affect other investment options, including allocation of loan volume (Riyadi, 2006; and Gupta and Jain, 2004).

Allocation of the collected funds into loan portfolios compared to other investment options could provide a positive impact for the bank. One of the most likely benefits is to earn interest income. Interest income has the highest promising return than other investment portfolios. Viewed from a risk perspective, banks are considered to have a better information of their customers than other institutions, including information related to credit customers. Before making loan decision whether to reject or accept loan application, banks are required to evaluate the creditworthiness of the applicant on the basis of prudential principles, as recommended by Central Bank of Indonesia. One of those is to assess creditworthiness using five $5 \mathrm{C}$ standard evaluation.

In addition, the ease of obtaining low-cost funds allows banks to overcome barriers that could occur in making a loan decision. The main source of bank funds comes from deposit saving collected from societies. Not all financial institutions are allowed to collect funds directly from societies, except banks. For example, other institutions such as insurance collected funds by offer insurance products. More, lately, it is getting an increase of trust from societies to banks since the cases of investment frauds becomes increase so that some people feel more comfortable and secure when placed their funds in the bank than other institutions. This the make banks become a priority for savings compared with other institutions. This then makes banks can possibly collect low-cost funds more than ever before.

This is also amplified by the ease of obtaining funding sources from other banks and Central Bank of Indonesia in form of loans. Under certain conditions, including when 
decided to expand more credit, banks can use loan funds obtained from other banks. This existing of trust level provides benefits not only for liquidity sources but also a cheap loan interest offered from other banks.

Apart from the above-given discussion, there are several measurements of loan performance noted by literature. One of the highest frequency of measurement ever use by scholars is Loan to Deposit Ratio called LDR(Taswan, 2010; Hemple and Simonson, 1999; Singkey, 1998; and Gupta and Jain, 2004). This is related to the ratio of the amount of loan disbursed by a bank divided by amounts of saving deposits collected by that particular bank. Recently, Central Bank of Indonesia issued a new measurement indicator called Loan to Funding Ratio. To put shorten the sentence, it is FDR. This is the ratio between the amount of loan distributed to societies against a number of saving deposits collected plus the issuance of securities undertaken by a particular bank for the purpose of obtaining funds.

In addition, credit performance can also be seen from the number of credit customers. In recent years, the format of bank financial statements is required to display the number of bank credit customers within a period of one year. In addition to the number of customers, credit performance can also be measured by a number of credit disbursements (Cziraky et al., 2005; Greenawalt and Sinkey, 1988).

This study uses a number of loans that have been allocated by a bank. This information can be obtained easily obtained from annual reports published by a bank. Therefore, the definition of credit volume used in this study refers to a number of loans that have been disbursed by a regional development bank within a particular period of one year.

\section{Personnel Cost}

Personnel cost incurred by bank consists of several components and each bank could possibly to have different items. For example, Bank Sulsebar measures personnel costs as wage and salary costs, job allowance cost, incentives, and education and training cost (Annual Report, 2016). Slightly different, the Bank of Papua uses both fixed and non-permanent wages, labor contribution cost, other wages, bonuses and incentives (Annual Report Bank Papua, 2016). More broadly, the Bank of West Nusa Tenggara (NTB) uses indicators in the form of production service cost, allowance cost, salary and wage cost, labor benefits, medication cost, leave over cost, and others. In this study, personnel cost is the sum of each of the costs incurred in the labor cost items presented in the end part of the annual report.

One factor that is very likely to have implications on loan volume is personnel cost. This assumption is valid because researchers found that there is a strong relationship between salary and/or wage paid by a company and employee productivities (Riley, 2005; and Benvenuti, et al, 2017). Related to bank case, high salaries reflected in personnel cost will certainly have a positive impact on the employee motivation (Delery, \& Doty, 1996; and Hermalin, \& Wallace, 2001). That motivation can impulse an effort to achieve the target of credit disbursement imposed to employees (Inderst, 2007 and Baker, 2000.). Of course, that is not just in the level of loan officers, salary could drive all employees to perform well (Agarwal and Wang, 2009). Those assigned on loan application appraisal may perform a time-efficient for the assessment made due to salary implication (Berg et al, 2012 and Godquin, 2004). It is also true for managers (Fahlenbrach \& Stulz, 2011). They will certainly 
actively motivate the employees to achieve the target stipulated, including the amount of loan distributed in the range of a particular time.

$\mathrm{H} 1$ : Amount of personnel cost affects positively and significantly loan volume.

\section{Advertising and Promotional Cost}

Advertising and promotion are one of the marketing efforts towards products and services offered. Certainly, these efforts are always associated with costs. With respect to a bank, the more efforts allocated for marketing activities, the greater the costs will be spent. Rationally, an institution will spend more cost on advertising and promotion when it is believed that the cost spent will drive an increase on, one of them, the demand for loans (Black \& Strahan, 2002).

In this study, advertising and the promotional cost is a number of funds spent by a bank in an effort to improve the image of the bank, which then could affect, one of them, loan demand or numbers of loan application. This will possibly affect amount of loan distributed by that bank (Škalamera-Alilović \& Štambuk, 2017 and Carter et al., 2007)

The relationship between advertising and promotional cost with loan volume can be described simply (Škalamera-Alilović \& Štambuk, 2017; Black \& Strahan, 2002; and Carter et al., 2007). It is the fact that there are still many people who do not understand the procedures of the loan application in the bank, and these people are commonly reluctant to make a contact with the bank. Such people will possibly apply for a loan from others such as cooperatives or apply for a loan from a moneylender. Consequently, they are required to pay a very high loan interest. This proves that promotional efforts may increase the likelihood of potential customers applying for loans.

Another aspect is that many banks provide a very wide coverage of a geographical operation assigned to a loan officer so that this makes some areas unexplored maximally. Through marketing efforts is likely to encourage people who are in a relatively remote location to obtain adequate information so that they will be able to apply for a cheap loan.

$\mathrm{H} 2$ : Amount of advertising and promotional cost affects positively and significantly loan volume

\section{Deposit Funds}

Third party funds are one of the largest sources of bank funds (Gupta et al., 2004 and Liu \& Wray, 2010). In fact, third-party funds are considered cheaper compared with obtaining a loan from others. From the existing literature, the source of funds from third parties is demand deposits, saving deposits, and time deposits (Gupta et al., 2004;). A demand deposit is a deposit from third parties to a bank whose withdrawal may be made at any time by check, other payment order or by way of transfer of the book. Thus, demand deposits are the shortest funding source as it is very easy to be transferred anytime (Kasmir, 2008; Rivai and Veithzal, 2007; and Riyadi, 2007) 
Aside from demand deposits, saving deposit is also the most common source of bank funds used to buffer lending activities (Darvas, 2013). Saving deposits are deposits from third parties to banks whose withdrawals may only be made under certain conditions. Saving deposit include a deposit on call, guarantee deposit, bonds, call money, interbank loans, receipt of funds from abroad and receipt of foreign currency funds (Kasmir, 2008; Rivai and Veithzal, 2007; and Riyadi, 2007). Other third-party funds are time deposits. This represents deposits from third parties to banks withdrawal may only be made within a certain period of time under an agreement between a third party and the bank concerned.

These deposits are the main source of funds for banks compared to other sources of funding. In various literature, it is said that this is a major buffer for lending (Kasmir, 2008; Rivai and Veithzal, 2007; and Riyadi, 2007). If the bank's third-party funds are low, then the bank will be forced to apply for another source of funds which could be more expensive than the deposit. When applying an extensive lending policy, it is usually followed by efforts to increase the number of deposits collected from societies (Shollapur and Baligatti, 2010 and Sudirman, 2003). Conversely, in the conditions that bank implement tightening lending strategies, the bank is more inclined reduce fund the collection from third-party (Darvas, 2013).

H3. Amount of saving deposits affects positively and significantly loan volume

\section{Economic Condition}

Economic condition is also one of the strongest external indicators that could affect loan supply decision(s). For this discussion, the study uses Gross Domestic Product (GDP) to describe the economic condition. Several studies employ economic condition as measure using various indicators such as inflation, interest and exchange rate, the balance of payment, and many others (Burton et al, 2001), which generally provide broad measurements. This study focuses a certain region in Indonesia; hence, GRDP is considered the most appropriate measurement to reflect the regional economic condition (Burton et al., 2003). we narrow down economic condition into the regional economic condition and define it as the degree of regional economic outlook in a certain area of a city or regency within a specific period of time.

Movements in GRDP are major determinants of shifts in demand for funds. When GDP rises, for example, there will be an increase in demand for loans from firms and household because GDP has improved the business outlook and household income (Burton et al., 2003) and likewise stimulates banks to provide more loans (Dell'Ariccia and Marquez, 2003; Eickmeier et al., 2008; and Blanchard, 2003) as they believe that borrowers become prospects, more willing to borrow and have the capability to borrow. on the other hand, when downturn economy occurred as indicated by decrease in GDP, the demand for funds decrease, and banks also have a tendency to face some external and internal obstacles, such as liquidity problems (Woodford, 2010), default rate (Keeton, 1999), tight regulation from central bank (Du and Kuttner, 2010; and Burton et al., 2003), and adverse selection problems (Gavin and Hausman, 1998; and Lowe and Rohling, 1992). Hence, banks' liability account could decline during the economic downturn, which in turn decreases loan supply decisions. Meaning that when the economy faces a downturn, there is the probability 
that loan volume will be low, and vice versa (Peek et al., 2003; and Gavin and Hausman, 1998).

H4: Output of Gross Regional Domestic Product affects positively and significantly loan volume

\section{Methodology}

\section{a. Sample, Data, and Procedures}

This study takes samples from 8 Regional Development Banks (RDBs) operating in Eastern Indonesia. These banks are Bank Sulselbar, Bank SulutGo, Bank Sulteng, Sultra Bank, Bank NTB, Bank NTT, Bank Maluku and Bank Papua. The data obtained for the research are taken from Annual Report of Bank RDBs and Indonesian Statistical Agency within the duration in between 2011 and 2016. Data from Annual Report of the Banks are loan volume, personnel operational cost, advertising, and promotional cost, total third-party funds. While GRDP output was taken from 12 provinces using Statistical Agency Data.

Table 1 : Descriptive Statistics for Main Variables

\begin{tabular}{|l|r|r|r|r|}
\hline Main Variable & \multicolumn{1}{|c|}{ Minimum } & \multicolumn{1}{c|}{ Maximum } & \multicolumn{1}{c|}{ Mean } & \multicolumn{1}{c|}{ Std. Deviation } \\
\hline Loan_volume & 491,997 & $7,882,680.00$ & $3,756,665.49$ & $2,009,839.07$ \\
\hline Promotional Cost & 761 & $26,653.00$ & $9,501.57$ & $7,183.43$ \\
\hline Personnel Cost & 26,610 & $477,898.00$ & $182,840.20$ & $1,077,188,694.00$ \\
\hline GRDP & 34,408 & $11,443,268.00$ & $3,749,665.98$ & $2,677,684.87$ \\
\hline Deposit Funds & 33,411 & $333,343.00$ & $96,769.71$ & $60,403.68$ \\
\hline
\end{tabular}

\section{b. Method of Data Analysis}

The study uses multivariate regression analysis. Beforehand, the data are tested to detect outlier and multicollinearity. Also, the study conduct normality test using the P$P$ plot. It was an outlier detection conducted firstly to avoid misreporting which could influence the regression line. To do so, the study uses Z score by applying SPPS version 23. On the basis of the statistical results, the study identifies three outlier scores, that are no 1 and 2 with respect to GRDP data, and 6 for personnel cost. When using z-score for outlier detection, the outlier data are lied out of z-score. The z-score lies in between negative 2.5 and positive 2.5 (Rousseeuw \& Hubert, (2017). These data are then dropped in the analysis as suggested by Orr et al, (1991).

Tabel 2 : Z-score value for the sample

\begin{tabular}{|l|l|r|}
\hline Zscore Value & Minimum & Maximum \\
\hline Zscore (Loan Volume) & -1.62434 & 1.91664 \\
\hline Zscore (Promotional Cost) & -1.21677 & 2.10131 \\
\hline Zscore (Personnel Cost) & -1.45035 & 2.54185 \\
\hline Zscore (GRDP) & -1.38749 & 3.19265 \\
\hline Zscore (Deposit Funds) & -1.04892 & 2.33473 \\
\hline
\end{tabular}


To avoid bias in the coefficient estimates and to specify the correct model in the given equation result, the study proposes to detect multicollinearity. With the use of Variance Inflation Factor (VIF) and tolerance, the results indicate that the lowest tolerance score is 0.201 and the highest VIF score is 3.19265. Widarono (2010) explains if using VIF and tolerance method, score tolerance is not to 0 and VIF score less than 10 means that there is no multicollinearity. On the basis of the given result, it can, therefore, be said that there is no multicollinearity.

Table 3: Multicollinearity Test

\begin{tabular}{|c|c|c|}
\hline \multirow{2}{*}{ Main Variable } & \multicolumn{2}{|c|}{ Collinearity Statistics } \\
\cline { 2 - 3 } & Tolerance & VIF \\
\hline Promotional Cost & 0.296 & 3.381 \\
\hline Personnel Cost & 0.201 & 4.982 \\
\hline GRDP & 0.333 & 2.999 \\
\hline Deposit Funds & 0.675 & 1.482 \\
\hline
\end{tabular}

Scholars noted that normal distribution is not needed when data have large samples (> 30 or 40 ) since the sampling distribution tend to be normal (Ghasemi \& Zahediasi, 2012; and Pallant, 2007). However, to ensure the data are normally distributed for the validity purpose, the study conduct normality test using the P-P plot. This is one of reliable normality distribution test counting on visual judgment (Ghasemi \& Zahediasl, 2012 and Altman \& Bland, 1995). From the test result using Probability Probability plot or called P-P plot of Standardized Residual regression, it can be seen that data can follow the existing diagonal line. Therefore, it can be concluded that this research data is normal.

Figure 1: Normality Distribution Test Using P-P Plot

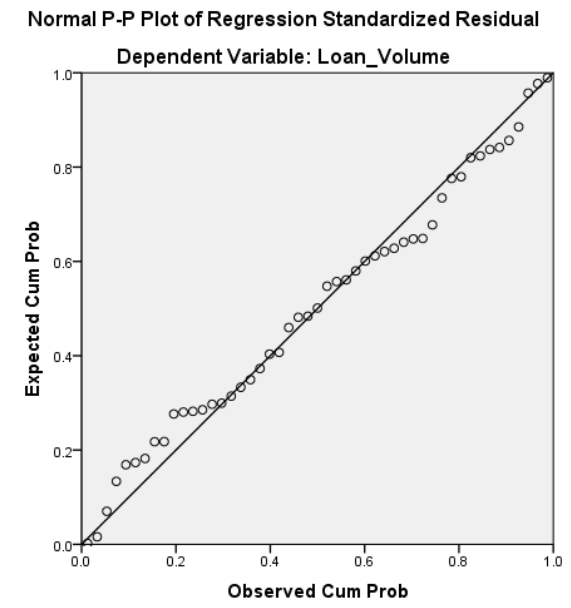

\section{Data Result and Analysis}

On the basis of multivariate regression analysis given in the table 4 , the regression equation is then formulated as $Y=561453+69,939 X 1+6,115 X 2+0,240 X 3+$ $5,098 \times 4+$ e. The result indicates that loan volume is predicted positively by four independent variables with a significant score of 0.00 . The four independent variables are the promotional cost (X1), personnel cost (X2), deposit funds (X3), and GRDP (X4). 
Table 4: Statistical Results Using Multivariate Regression Analysis (F-test).

\begin{tabular}{|c|c|c|c|c|c|c|}
\hline \multicolumn{7}{|c|}{ ANOVA } \\
\hline \multicolumn{2}{|c|}{ Model } & Sum of Squares & $\mathrm{df}$ & Mean Square & $\mathrm{F}$ & Sig. \\
\hline \multirow[t]{3}{*}{1} & Regression & $\begin{array}{r}131379873161545.9 \\
80\end{array}$ & 4 & 32844968290386.496 & 54.705 & $.000^{\mathrm{b}}$ \\
\hline & Residual & $\begin{array}{r}24616540856188.91 \\
8\end{array}$ & 41 & 600403435516.803 & & \\
\hline & Total & $\begin{array}{r}155996414017734.9 \\
00\end{array}$ & 45 & & & \\
\hline \multicolumn{7}{|c|}{ a. Dependent Variable: Loan_Volume } \\
\hline \multicolumn{7}{|c|}{ b. Predictors: (Constant), GRDP, Promotion, Deposit_Funds, Personnel_Cost } \\
\hline
\end{tabular}

The determination coefficient parameter as given in table 5 is 0.827 or $82,7 \%$. This means that the four predictors variable explain $82,7 \%$ of the variance and $17,3 \%$ of the variance cannot be explained the studied variable. It also can be said that variation of the total loan volume can be explained by variation of promotional cost (X1), personnel cost (X2), Deposit Funds (X3), and GRDP (X4) as much as is 0.842 or $84,2 \%$, the rest 0.158 or $15.8 \%$ is explained by other variables. With the use of adjusted $R$ square, it is as much as 0.827 or $82.7 \%$.

Table 5: Statistical Results of the Determination Coefficient

\begin{tabular}{|c|c|c|c|c|}
\hline \multicolumn{5}{|c|}{ Model Summary } \\
\hline Model & $\mathrm{R}$ & R Square & Adjusted R Square & $\begin{array}{l}\text { Std. Error of the } \\
\text { Estimate }\end{array}$ \\
\hline 1 & $.918^{\mathrm{a}}$ & .842 & .827 & 774857.042 \\
\hline
\end{tabular}

The partial influence of each variable is examined using t-value. Statistical t-test indicates that there are three variables show a significant result of less than 0.05 and one predicted variable show insignificant value. Those three variables are the promotional cost (0.024), personnel cost (0.026), and deposit funds (0.003). Another predicted variable of GRDP show insignificant score of $0,114(0.114>0.05)$.

The coefficient score of the variable promotional cost is 69.939. This means that when a bank expenditure of promotional cost increase 1 unit ( 1 million rupiah), the total loan volume will increase to 69,939 rupiah. The coefficient parameter of the personnel cost is 6.115 with assumption other variables unchanged. It means that when the cost of personnel is increased by 1 unit (1 million), the total volume of the loan will increase to 6.115 million rupiah with assumption other variables unchanged. With regard to deposit funds, the coefficient parameter is 0.240 . This indicates that when deposit funds increase 1 unit (million), then the total volume of the loan will increase to 0.240 million rupiah with assumption other variables unchanged. To GRDP, its coefficient score is 5.098. This means that when the output of GRDP increase to 1 unit ( 1 billion rupiah), the total volume of the loan will increase to 5.098 million rupiah with assumption other variables unchanged.

Viewed from its individual contribution of each variable, standardized coefficient (beta) shows that deposit funds $(0.338)$ have a higher impact to the total volume of 
the loan, then followed by personnel cost (0.319), promotional cost $(0.267)$, and GRDP (0.122).

Table 6: Statistical Results Using Multivariate Regression Analysis (t-test).

\begin{tabular}{|c|c|c|c|c|c|c|}
\hline \multicolumn{7}{|c|}{ Coefficients } \\
\hline \multicolumn{2}{|c|}{ Model } & \multicolumn{2}{|c|}{ Unstandardized Coefficients } & \multirow{2}{*}{$\begin{array}{c}\text { Standardized } \\
\text { Coefficients } \\
\text { Beta }\end{array}$} & \multirow[t]{2}{*}{$t$} & \multirow[t]{2}{*}{ Sig. } \\
\hline & & $B$ & Std. Error & & & \\
\hline \multirow[t]{5}{*}{1} & (Constant) & 561453.027 & 291443.991 & & 1.926 & .061 \\
\hline & Promotional_cost & 69.939 & 29.920 & 267 & 2.338 & .024 \\
\hline & Personnel_Cost & 6.115 & 2.655 & 319 & 2.303 & .026 \\
\hline & Deposit_Funds & .240 & .076 & .338 & 3.149 & .003 \\
\hline & GRDP & 5.098 & 3.160 & 122 & 1.614 & .114 \\
\hline
\end{tabular}

\section{Discussion and Implication}

Given the result in table 4, it can be explained that an increased expenditure in promotional costs will cause an increase in the amount of loan volume granted. This is in line with findings by some researchers (Škalamera-Alilović \& Štambuk, 2017 and Carter et al., 2007; and Tankha, 2002). This implies that when a bank implements loan expansion strategy, then it will be effective if it is followed by an increased expenditure on promotional costs since the costs could predict an increasing amount of loan volume distributed. Conversely, it could be that bank may do not eager to spent much of promotional cost when, one of them, it does apply a tight lending policy.

This is also valid for the cost of personnel in which an increased expenditure on promotional costs could increase loan volume. This finding is consistent with Berg et al, (2012), Riley, (2005), Benvenuti et al, (2017), Inderst, (2007), and Agawal and Wang, 2009). It can be explained that an increase in personnel cost can drive up efforts to make more credit decisions, in particular, to loan officers. In other words, an increase in wage could make loan officer of the bank to achieve more credit realization against the target set. However, some studies found a negative relationship to the quality of credit disbursed. The increase in loan volume could cause more bad credit decision made by loan officers (Agarwal et al, 2014 and Banerjee et al. (2009).

Deposit funds also have an impact on the increase in the amount of loan volume. This has been corroborated by the findings of researchers in various countries, such as in India (Shollapur and Baligatti, 2010), in Japan (Ogawa \& Kitasaka, 2000), and in Indonesia (Sudirman, 2003). This is true because deposits are the main funds used to support lending activities, particularly short-term loans (Taswan, 2010; Gupta et al, 2004). This is also amplified that deposit funds are a relatively cheap source of funds and the funds are easy to obtain compared to other sources of funds. Thus it can be said when loan expansion strategy made by a bank, then it will seek a way to increase deposit funds. Conversely, in a condition where the bank implements a tightening loan policy, then the effort to obtain deposit funds will also decrease.

Economy activity is often associated with loan supply which then could affect the total amount of loan volume. If there is an increase in economic activity, it is likely that people will seek for more loans in the use of consumption and business purpose. This desire arises because the increase in economic activity makes people and 
businesses feel confident that they will be able to perform loan repayment. This argument is supported by Burton et al., (2003) Dell'Ariccia and Marquez (2003), Eickmeier et al. (2008), and Blanchard (2003).

\section{Conclusion}

This research study about a variable that could predict loan volume. One of the measurements used by the researcher for a loan is loan volume. The increase in loan volume can be predicted through promotional costs, personnel costs, deposit funds and GRDP output. An increase in the cost of promotion can drive total volume of loans disbursed. This also applies to personnel costs. An increase in salaries and wages, bonuses, and other financial incentives can lead to an increase in the total of loan volume booked by the bank. This also happens to deposit funds. An increase in deposit funds could lead to an increase in the amount of credit disbursement as deposit funds are the main buffer for lending activities. For GRDP, an increase in GRDP output will also encourage the growing volume of loans. This is because economic activity will trigger loan demand from societies, including business industries. 


\section{REFERENCES}

Agarwal, S., Amromin, G., Ben-David, I., Chomsisengphet, S., \& Evanoff, D. D. 2014. "Predatory lending and the subprime crisis". Journal of Financial Economics, 113(1), 29-52.

Agarwal, Sumit, and Faye H. Wang, 2009. "Perverse incentives at the banks? Evidence from a natural experiment," No. 2009-08, Working Paper, Federal Reserve Bank of Chicago.

Agustina, V. U., Djaelani, A. Q., \& Priyono, A. A. 2017. "Pengaruh Tingkat Kesehatan Finansial Perusahaan terhadap Pertumbuhan Laba pada Perbankan Syariah di Indonesia (Studi Kasus Pada Bank Umum Syariah di Indonesia Tahun 2012-2016)". Jurnal Ilmiah Riset Manajemen, 6(02).

Altman, D. G., \& Bland, J. M. 1995., "Statistics notes the normal distribution". Bmj, 310 (6975), 298.

Almazan, A., \& Suarez, J. 2003." Managerial compensation and the market reaction to bank loans". The review of financial studies, 16(1), 237-261.

Almossawi, M. 2001. "Bank selection criteria employed by college students in Bahrain: an empirical analysis". International Journal of Bank Marketing, 19(3), 115-125.

Anindita, I., \& Arfianto, E. D. 2011. "Analisis Pengaruh Tingkat Suku Bunga, CAR, NPL Dan LDR terhadap penyaluran kredit UMKM"., (studi pada bank umum swasta nasional periode 2003-2010) (Doctoral dissertation, Universitas Diponegoro).

Anwar, M. 2017., "The Effect of Lending Portfolios to Small Business on Bank Profitability and Interest Margin: Study on State-Owned Banks and Local Government-Owned Banks in Indonesia". Jurnal Keuangan dan Perbankan, 15 (2) $173-190$.

Baker, G. 2000. The use of performance measures in incentive contracting. The American economic review, 90(2), 415-420.

Bank Sulselbar, 2016. Annual Report of Bank Sulselbar.

Bank Papua, 2016. Annual Report of Bank Papua

Bank NTB, 2016. Annual Report of Bank NTB.

Banerjee, A.; Cole, S.; and Duflo, E., 2009, "Default and Punishment: Incentives and Lending Behaviour in Indian Banks", Working Paper Series.

Benvenuti, M., Casolaro, L., Del Prete, S., \& Mistrulli, P. E. 2017. "The Right to Decide and the Effective Control Over Small Business Lending Decisions: A Look into Loan Officers' Real Authority”. Economic Notes, 46(2), 237-268.

Berg, T., Puri, M., and Rocholl, 2012 "Loan Officer Incentives and the Limits of Hard Information,", Working Paper Series of Duke University, (Duke University).

Bernardin, D. E. Y. 2016. "Pengaruh CAR dan LDR terhadap Return on Assets". Jurnal Ecodemica, 4 (2), 232-241

Blanchard, Oliver., 2003 "Macroeconomics, International Edition", $3^{\text {rd }}$, (Prentice Hall, United States of America.

Black, S. E., \& Strahan, P. E. 2002. "Entrepreneurship and bank credit availability". The Journal of Finance, 57(6), 2807-2833.

Burton, M., Nesiba, R., and Lombra, R. 2003.,"An Introduction to Financial Markets and Institutions, (United States, South-Western).

Carter, S., Shaw, E., Lam, W., \& Wilson, F. 2007., "Gender, entrepreneurship, and bank lending: The criteria and processes used by bank loan officers in 
assessing applications". Entrepreneurship Theory and Practice, 31(3), 427444.

Chi, Q., \& Li, W. 2017., "Economic policy uncertainty, credit risks and banks' lending decisions: Evidence from Chinese commercial banks". China Journal of Accounting Research. 10 (1) 33-50.

Darvaz, Z., 2013., "Banking System Soundness is the key to more SME financing," Working Paper of Directorate General for Internal Policies, Policy Department A: Economic and Scientific Policy, Brugel Policy Contribution, Available at http://www.europarl.europa.eu/document/activities/cont/201307/20130712ATT 69731/20130712ATT69731EN.pdf

Delery, J. E., \& Doty, D. H. 1996., "Modes of theorizing in strategic human resource management: Tests of universalistic, contingency, and configurational performance predictions". Academy of Management Journal, 39(4), 802-835.

Dell'Ariccia, G., and Marquez, R., 2003., "Lending Booms and Lending Standards", The Journal of Finance, no 5, 2003, vol 61 2511-2546.

Du, Y., and Kuttner, K.N., 2010., "Monetary Policy and Bank Loan Supply in China", Master Thesis in Economics, Williams College., Massachusetts.

Eickmeier, S., Hofmann, B., and Worms, A., 2008., "Macroeconomic Fluctuations and Bank Lending: Evidence for Germany and the Euro Area, German Economic Review, no 2, 2008, vol 10, 193-223.

Eletter, S. F., \& Yaseen, S. G. 2017., "Loan decision models for the Jordanian commercial banks". Global Business and Economics Review, 19(3), 323-338.

Elliott, A. C., \& Woodward, W. A. 2007., Statistical analysis quick reference guidebook: With SPSS examples. Sage.

Fahlenbrach, R., \& Stulz, R. M. 2011., Bank CEO incentives and the credit crisis. Journal of financial economics, 99(1), 11-26.

Field, A. 2013., Discovering statistics using IBM SPSS statistics. Sage.

Godquin, M. 2004., "Microfinance repayment performance in Bangladesh: How to improve the allocation of loans by MFIs". World Development, 32 (11), 19091926.

Gavin, M., and Hausmann., "The roots of Banking Crises: The Macroeconomic Context, Working Paper Series of Inter-American Development Bank, (Washington DC 1998).

Ghasemi, A., \& Zahediasl, S. 2012., "Normality tests for statistical analysis: a guide for non-statisticians". International journal of endocrinology and metabolism, 10 (2), 486.

Gupta, V. and Jain, P.K., 2004., "Liability Management in Commercial Banks in India: A Comparative Study of Bank Groups in Liberalized-Era", Global Journal of Flexible System Management, no 4, vol 5, 53-66.

Hanweck, G., and Ryu, L., 2005., "The Sensitivity of Bank Net Interest Margins and Profitability to Credit, Interest-Rate, and Term-Structure Shocks Across Bank Product Specialisations", Working Paper Series.

Hempel, G.H., and Simonson, D.G., 1999., "Bank Management: Text and Cases", $5^{\text {th }}$ Edition, United State of America., John Wiley \& Son, Inc.

Hermalin, B. E., \& Wallace, N. E. 2001., "Firm performance and executive compensation in the savings and loan industry". Journal of Financial Economics, 61 (1), 139-170.

Inderst, Roman., 2007., "Opening the Black Box: Implication of a Model of the Loan Origination Process for Lending Standards and the Switch from Soft to Hard Information Lending", Working Paper Series of London School of Economics, University Frankfurt, IMFS. 
Kasmir., “Manajemen Perbankan" 2008., Rajawali Pers, ISBN: 0794217948, Rajawali Pers .

Keeton, W.R., .1999., "Does Faster Loan Growth Lead to Higher Losses?," Economic Review of Federal Reserve Bank of Kansas City.

Lin, D., Foster, D. P., \& Ungar, L. H. 2011., "VIF regression: a fast regression algorithm for large data". Journal of the American Statistical Association, 106 (493), 232-247.

Liem, C., Masjud, Y. I., \& Candra, A. W. 2017., Local-Government-Owned Commercial Banks' Performance Influencer Factors in Indonesia. Firm Journal of Management Studies, 2 (1) 180-190.

Lepetit, L., Nys, E., Rous, P., \& Tarazi, A. 2008., "The expansion of services in European banking: Implications for loan pricing and interest margins". Journal of Banking \& Finance, 32(11), 2325-2335.

Liu, Xinhua., and Wray, L. Randall., 2010., "Excess Liquidity and Banking Lending in China. A Modern Money Perspective, International Journal of Political Economy, no 3, vol 39, 45-63.

Lowe, P., and Rohling, T., 1992., "Loan Rate Stickiness: Theory and Evidence", Working Paper Series of Reserve Bank of Australia.

Macerinskine, I., and Ivaskevicute, L., 2008., "The Evaluation Model of Commercial Bank Portfolio", Journal of Business Economics and Management, no 4, vol 9, 269-277.

Njeru, M., Mohhamed, S., \& Wachira, M. A. 2017., "Effectiveness of Credit Management System on Loan Performance of Commercial banks in Kenya". International Journal of Finance and Accounting, 2(4), 106-122.

Ogawa, K., \& Kitasaka, S. I. 2000., "Bank lending in Japan: its determinants and macroeconomic implications". Crisis and Change in the Japanese Financial system, 159-199.

Orr, J. M., Sackett, P. R., \& Dubois, C. L. 1991., "Outlier detection and treatment in I/O psychology: A survey of researcher beliefs and an empirical illustration". Personnel Psychology, 44 (3), 473-486.

Pallant J. 2008., SPSS survival manual, a step by step guide to data analysis using SPSS for windows. 3 ed. Sydney: McGraw Hill. pp. 179-200.

Peek, J., Rosengree, E. S., and Tootle., 2003., "Identifying the Macroeconomic Effect of Loan Supply Shocks", Journal of Money, Credit, and Banking (Ohio State University Press), no 6, vol 35, 931 - 946.

Pelealu, I., Karamoy, H., \& Poputra, A. T. 2017., "Analisa Perbandingan Kinerja Berdasarkan CAMELS pada Bank yang Terdaftar di Otoritas Jasa Keuangan". Jurnal Riset Akuntansi dan Auditing Goodwill, 8 (1).

Qudraty, M., \& Suriani, S. 2017., "Efektifitas Kebijakan Makroprudensial Perbankan dan Penyaluran Kredit di Aceh". Jurnal Perspektif Ekonomi Darussalam, 2(1), 32-53.

Raharjo, P. G., Hakim, D. B., "Manurung, A. H., \& Maulana, T. N. 2014., The Determinant of Commercial Banks' Interest Margin in Indonesia: An Analysis of Fixed Effect Panel Regression". International Journal of Economics and Financial Issues, 4 (2), 295.

Ramcharran, H. 2017., "Bank lending to small business in India: Analyzing Productivity and Efficiency". The Quarterly Review of Economics and Finance, 65, 16-24.

Riley, Shannon., 2005., "Herzberg's Two-Factor Theory of Motivation Applied to the Motivational Techniques within Financial Institutions", Published Thesis of Eastern Michigan University. 
Rivai, V., and Veithzal, P., 2007., "Credit Management Handbook: Teori, Konsep, Prosedur, dan Aplikasi Panduan Praktis Mahasiswa, Bankir, dan Nasabah", Edisi Pertama, Published by PT. Raja Grafindo .

Riyadi, S. 2017., "Financial performance efficiency of Indonesia government banks in improving profitability". International Journal of Financial Innovation in Banking, 1(3-4), 239-252.

Riyadi, Slamet., 2006., "Banking Assets and Liability Management", Edisi Ketiga, Fakultas Ekonomi Universitas Indonesia, (Fakultas Ekonomi UI).

Rokhim, R., \& Harmidy, J. A. 2017., "Ownership Structure, Risk, and Their Impact Towards Performances in Indonesian Commercial Banks". Jurnal Keuangan dan Perbankan, 15 (1) 22 - 37.

Rosengard, J. K., \& Prasetyantoko, A. 2011., "If the banks are doing so well, why can't I get a loan? Regulatory constraints to financial inclusion in Indonesia". Asian Economic Policy Review, 6(2), 273-296.

Rousseeuw, P. J., \& Hubert, M. 2017., "Anomaly Detection by Robust Statistics". arXiv preprint arXiv:1707.09752.

Satria, D., \& Subegti, R. B. 2010., "Determinasi Penyaluran Kredit Bank Umum di Indonesia Periode 2006-2009". Jurnal Keuangan dan Perbankan, 14(3), 415424.

Shollapur, M.R., and Baligatti, Y.G., 2010., "Funds Management in Banks: A CostBenefit Perspective", International Business and Economics Research Journal, no 11, vol 9, $21-29$.

Singkey, Josepth F., 1998., "Commercial Bank Financial Management", $5^{\text {th }}$ Edition, United State of America, Prentice-Hall, Inc. Publishing.

Škalamera-Alilović, D., \& Štambuk, A. 2017., "Commercial Banking and Personal Indebtedness in Croatia". Megatrend Review, 14 (1) 187 -206.

Sudirman, I. W., 2003., "Faktor-Faktor Penghambat Peningkatan Loan to Deposit Ratio (LDR) Perbankan di Provinsi Bali", Journal of Indonesian Economy and Business, $\mathrm{p}$ (nd).

Sukarno, K. W., \& Syaichu, M. 2006., "Analisis faktor-faktor yang mempengaruhi kinerja bank umum di Indonesia”. Jurnal Studi Manajemen Organisasi, 3 (2), 46-58.

Tankha, A. 2002., "Self-help groups as financial intermediaries in India: Cost of promotion, sustainability, and impact"., New Delhi: Sa-Dhan, study prepared for ICCO and Cordaid, The Netherlands.

Taswan., 2010., "Manajemen Perbankan: Konsep, Teknik and Aplikasi,", Edisi Pertama, (UPP STIK YKPN Yokyakarta.

Triasdini, H., \& Arifianto, E. D. 2010., "Pengaruh CAR, NPL Dan ROA Terhadap Penyaluran Kredit Modal Kerja (Studi Pada Bank Umum Yang Terdaftar Di Bursa Efek Indonesia Periode 2004-2009”.,) (Doctoral dissertation, Universitas Diponegoro).

Wahyuningsih, T., Oemar, A., \& Supriyanto, A. 2017., "Pengaruh CAR, NPF, FDR, BOPO, dan GWM terhadap Laba Perusahaan (ROA) pada Bank Umum Syariah di Indonesia Periode 2010-2015". Journal Of Accounting, 3 (3).

Wahyuningsih, T., \& Swandari, F. 2016., "Perbandingan NPL, LDR, CAR, ROA, dan BOPO Antara Bank BNI Dan Bank BUMN Lain"., Jurnal Wawasan Manajemen, 4 (2), 165-173.

Wibowo, E. S., \& Syaichu, M. 2013., Analisis Pengaruh Suku Bunga, Inflasi, CAR, BOPO, NPF Terhadap Profitabilitas Bank Syariah. Jurnal Manajemen Diponegoro, 2(2), 1-10. 
Woodford, Michael., 2010., "Financial Intermediation and Macroeconomic Analysis", Journal of Economic Perspectives, no 4, vol 24, 21 - 44. 